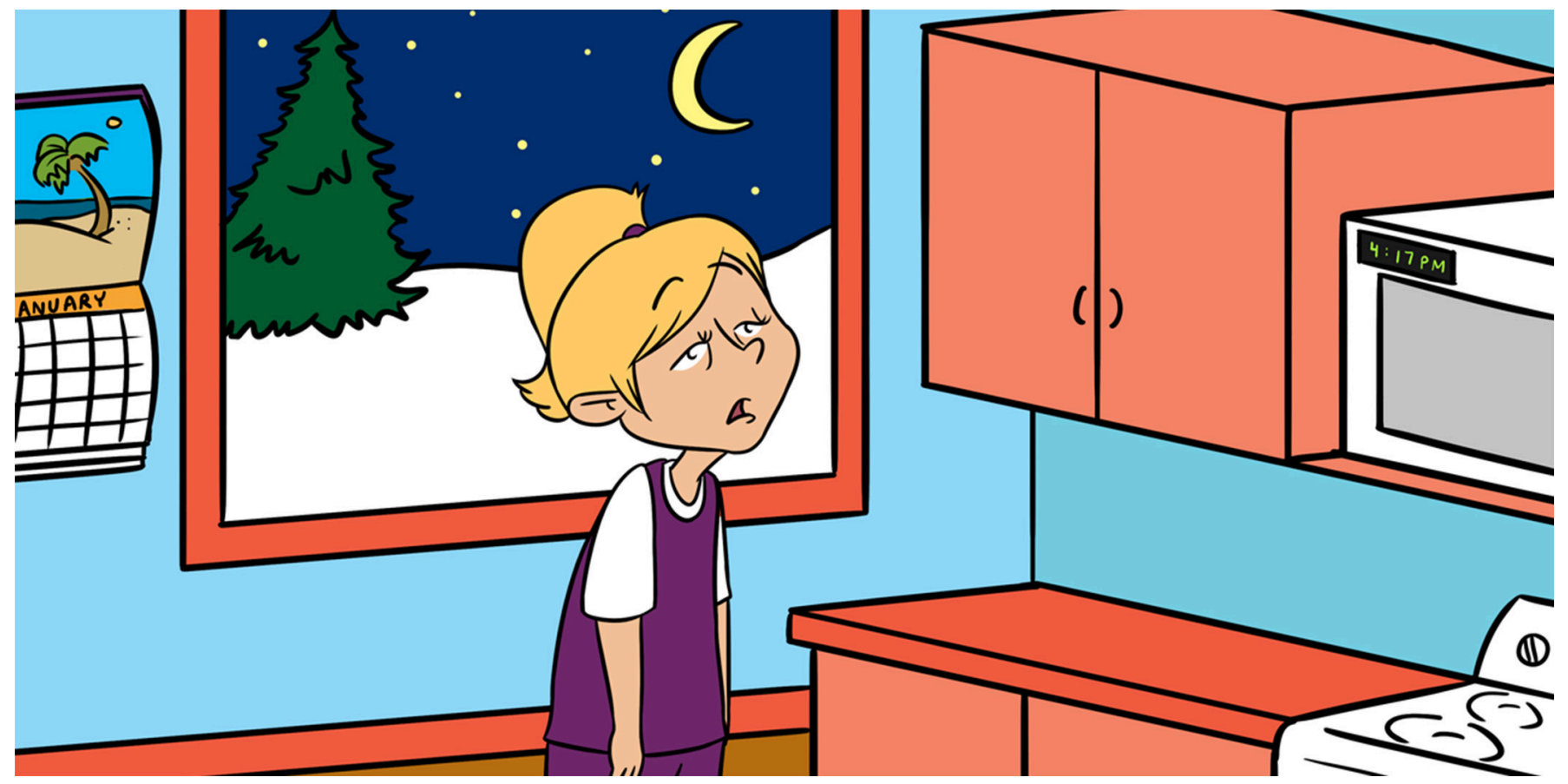

\title{
THE IMPORTANCE OF KEEPING TIME WITH OUR INTERNAL CLOCKS
}

\section{Katie L. Birchard ${ }^{1}$ and Deborah M. Leigh ${ }^{1,2^{*}}$}

${ }^{1}$ Department of Biology, Queen's University, Kingston, ON, Canada

${ }^{2}$ Swiss Federal Institute for Forest, Snow and Landscape Research (WSL), Birmensdrof, Switzerland

\section{YOUNG REVIEWERS:}

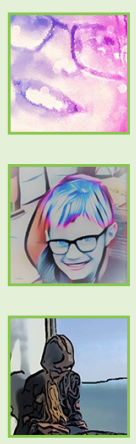

CAITLIN

AGE: 12

EDWARD

AGE: 11

LOLA

AGE: 12
Have you ever noticed that you feel awake when it is light outside, but sleepy when it is dark? Our bodies know to get up in the morning and go to sleep at night because of our circadian rhythms. Circadian rhythms, also known as internal clocks, control important bodily processes to help you know when you are hungry, thirsty, and sleepy. These clocks are present in every living thing (even bacteria!). They can cycle over a day, but also on a longer time scale. Circannual rhythms, for example, keep a schedule that stretches over 365 days. These longer rhythms are most visible in spring and winter, when you see tulips flowering, bears hibernating, or birds migrating. Our genes (units of information passed down from our parents) and cues from the environment, like light, temperature, food, or stress, all affect our internal clocks. 
Figure 1

An example of an internal clock on a 24-h time scale. At certain times throughout the day your body behaves or feels differently. For example, between 10:00 and $12: 00$ you may feel focused and energetic, but between $14: 00$ (2:00 p.m.) and 16:00 (4:00 p.m.) you may feel like it is time to take a nap. Internal clocks can also take place on a 365-day time scale (not pictured).

\section{CIRCADIAN}

RHYTHM

\section{A 24-h internal clock} set by a combination of genes and environment that cycles through bodily processes on a daily basis.

\section{CIRCANNUAL RHYTHM}

\section{A 365-day internal clock set by a combination of genes and environment that cycles through behavioral and bodily processes, such as hibernation, on a yearly basis.}

\section{GENE}

A section of DNA that is passed down from our parents and acts as the code to produce small molecules, called proteins, that carry out specific jobs around the body.

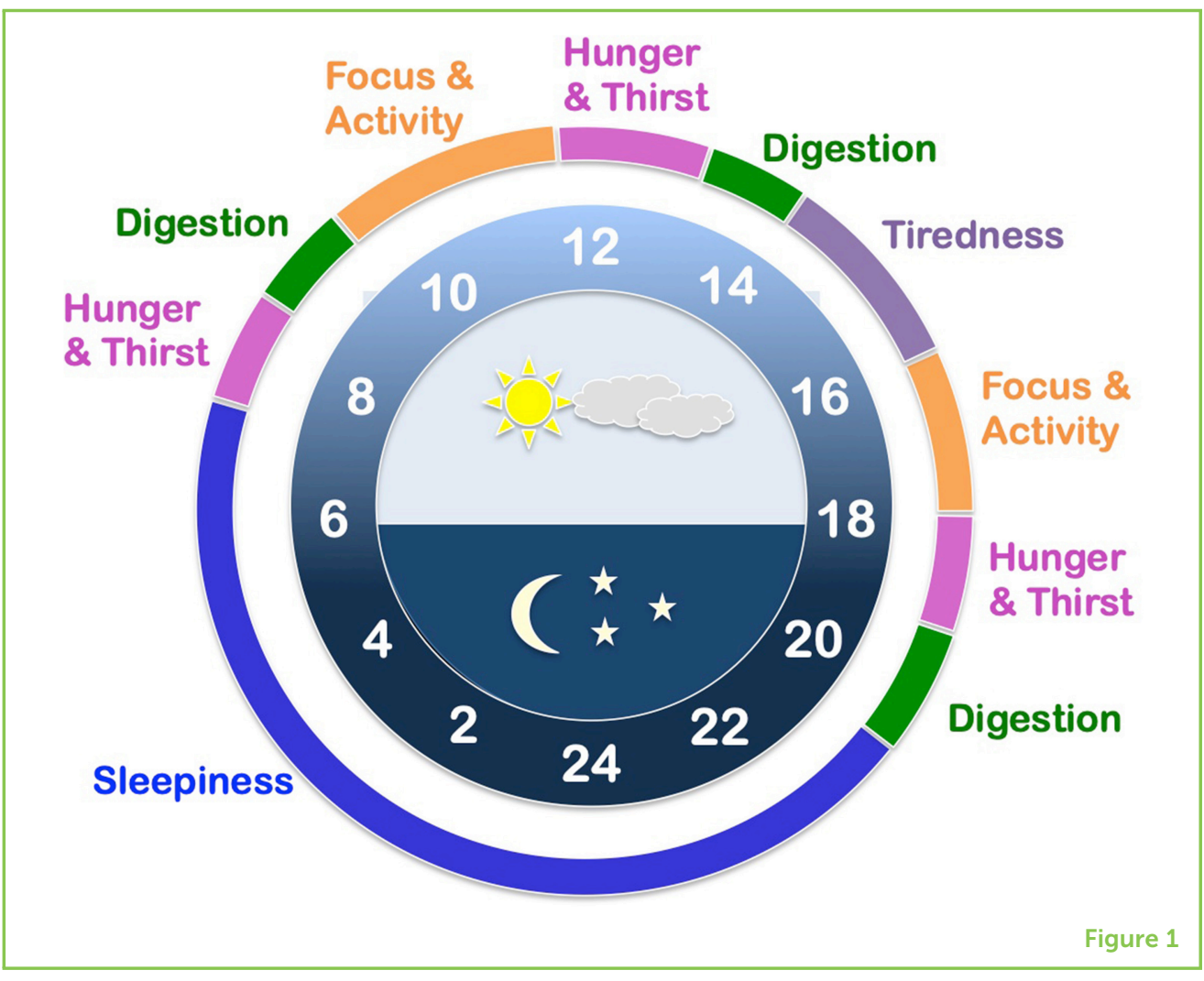

\section{INTRODUCTION}

The way your body feels and behaves changes throughout the day and throughout each year. Our daily changes are due to circadian rhythms and our yearly changes are due to circannual rhythms. These rhythms, also known as our internal clocks, keep time by tracking changes in our surroundings. Changes include yearly variations in temperature or daily changes in light levels. Thanks to these environmental cues, our internal clocks can determine whether we feel awake, tired, hungry, or sad (Figure 1). If we did not have these internal clocks, we would not feel the right things at the right times. For instance, if you did not feel tired at night, then you would probably not go to bed. This would be bad for your health, because your brain would not have the rest it needs to function properly. Circannual rhythms, internal clocks that run over a year, also influence bodily processes that we are not even aware of. This can include how we digest our meals and break down food into nutrients and energy.

\section{WHAT MAKES UP THE INTERNAL CLOCK?}

Our daily internal clocks are controlled by genes, which are small units of DNA passed down from our parents [1]. These genes contain the code to produce proteins-molecules in the body that carry out specific jobs. Some of the genes that control our internal clocks 
Figure 2

Our internal clocks are controlled by genes that produces proteins called activators and suppressors. (A) Some activators need to bind to each other before they can bind to a gene and turn it on. (B) Suppressors come between the activators and the gene to prevent them from turning the gene on.

\section{ACTIVATOR}

Protein(s) that bind to a gene to turn it on: sometimes, the activators can only bind to a gene after they bind to each other (like in our internal clocks).

\section{SUPPRESSOR}

Protein(s) that work to turn a process off by either binding to a gene directly, or preventing activators from binding to the gene (like in our internal clocks).

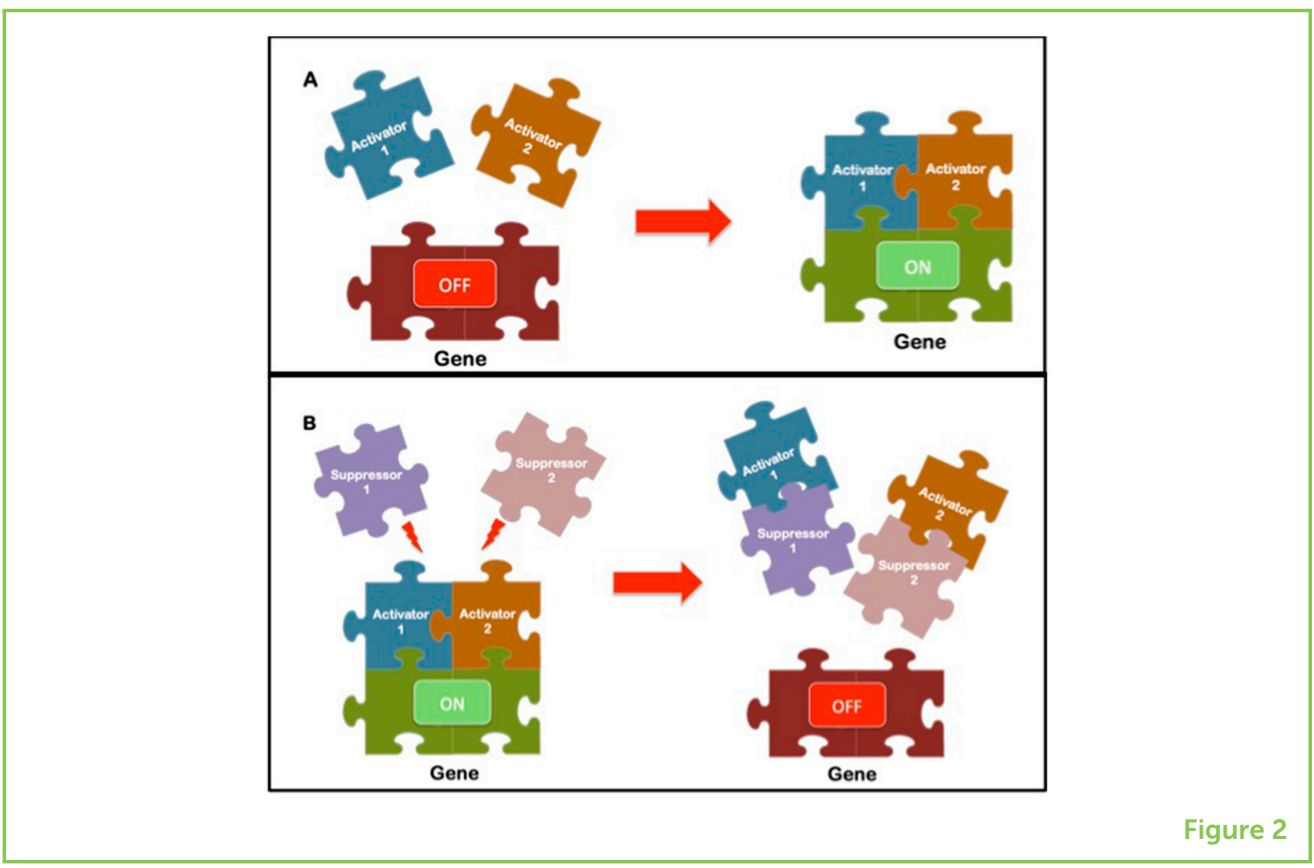

produce proteins called "activators" and others produce proteins called "suppressors." Activators are proteins that turn a gene on, whereas suppressors are proteins that turn a gene off (Figure 2). In our daily internal clocks we need two activators to bind together to turn on a gene (Figure 2A). This gene is usually turned on in the morning. Once this gene is turned on, lots of different proteins are made, including the two suppressors [1]. When there are lots of these suppressor proteins being made, we typically feel energetic and lively! Throughout the day, the concentration of these suppressor proteins increases in our bodies. By the evening, enough suppressor proteins are made to block the activators and turn off the gene (Figure 2B) [1]. While you sleep, the suppressors in the bloodstream break down [1]. During this breakdown, which occurs at nighttime, we feel tired and sleepy. Another protein is also produced during the nighttime-a protein called "melatonin"-that helps to keep our circadian clocks on time [1]. Once the suppressors have completely broken down, the activators are no longer prevented from binding together or to the gene, and the cycle repeats itself (Figure 3).

\section{WHAT ROLE DO CIRCADIAN RHYTHMS PLAY IN HUMAN HEALTH?}

Circadian rhythms are essential for human health, and problems can occur when environmental cues set the wrong time on our internal clocks. A common clock disruption is the use of technology with artificial light at night. For example, light from a tablet or a phone screen can disrupt our daily clock. Melatonin, the protein that keeps our clock genes in check, is influenced by exposure to light [1]. In darkness, our bodies get the signal to start producing large amounts 


\section{Figure 3}

The complete cycle of how the genes interact in our internal clocks over a 24-h time period. During the day, the activators bind to each other and turn on genes involved in our internal clocks. These genes produce suppressors. At this time, our melatonin levels are low, and we feel awake. Throughout the day, the number of suppressors in the body grows. During the night, the large number of suppressors works to break apart the activators and turn off the genes before breaking down themselves. At nighttime, our melatonin levels are high, and we feel sleepy.

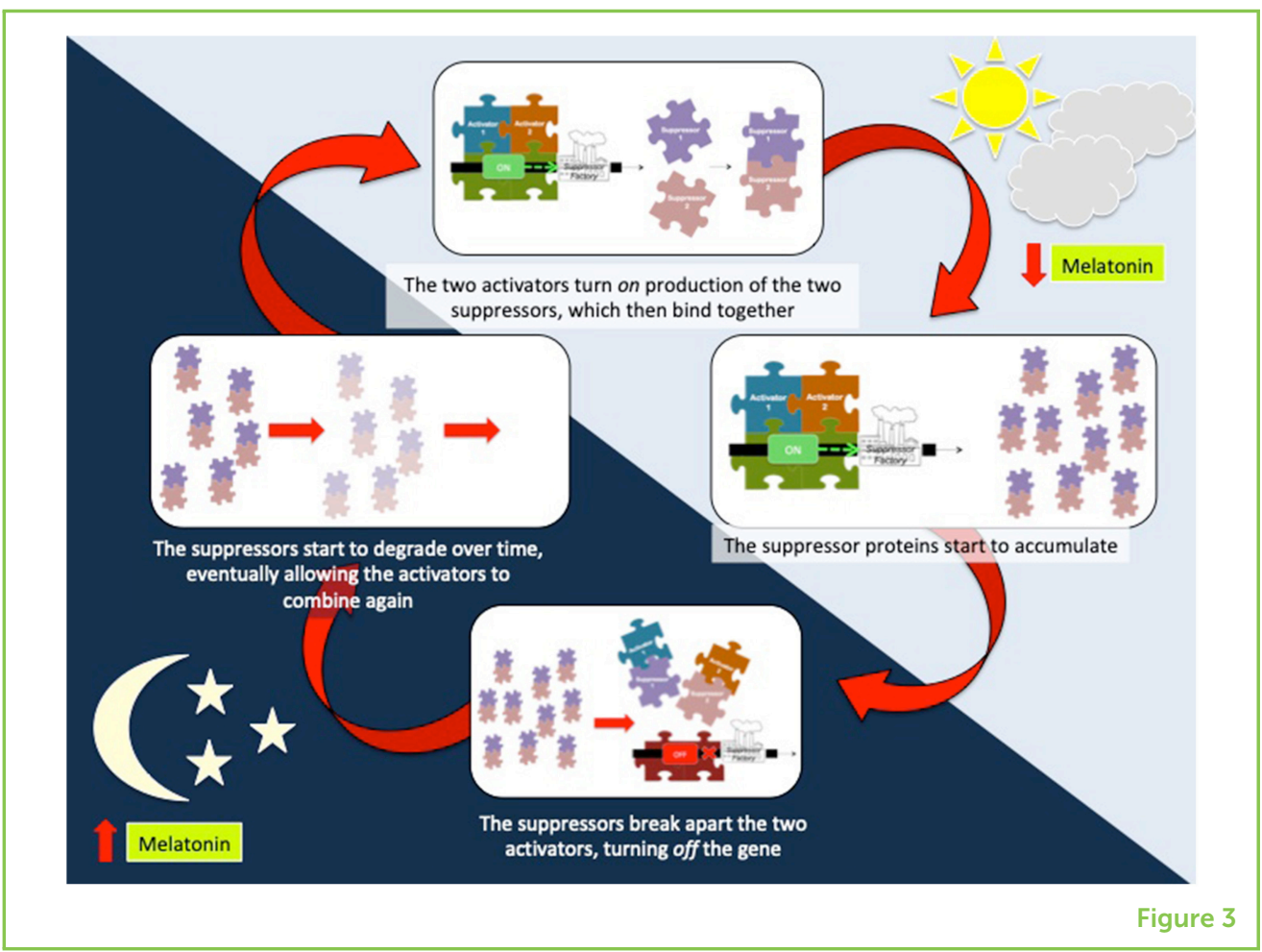

of melatonin, making us sleepy and ready for bed. However, we do not produce a lot of melatonin when exposed to light. Light from our phones can trick our bodies into thinking it is still daytime, making it harder to fall asleep and making us more tired in the morning. Interestingly, only certain colors of light act as signals to start melatonin production. In particular, light waves with shorter wavelengths, such as purple or blue light, effectively stop melatonin production [2]. By filtering out this blue light using blue-blocking glasses or apps on a phone or tablet, the brain does not get the message to stop producing melatonin and we will not experience the negative effects of artificial light at night [2].

Another way we can disrupt our internal clocks is by not getting enough sleep at night or sleeping during the day. Things, such as taking an airplane to a new time zone or setting our alarms too early can disrupt our circadian rhythms. Sleeping too little leads to well-known problems such as: lack of concentration, difficulty learning, and slowed reaction times [1]. You may have also noticed that after a bad night's sleep you are grumpy, feel sadder, or may have trouble communicating with the people around you [1]. Disrupting the natural rhythm of our internal clocks can even lead to poor digestion, heart problems, weight gain, and a weakened immune system [1]. For instance, scientists discovered that individuals not getting enough sleep at night had immune systems that produced infection-fighting proteins at the wrong time of day-meaning these proteins were not available during actual times of infection [3]. However, scientists also discovered that with a consistent full $8 \mathrm{~h}$ of sleep for at least 5 days, their immune systems went back to normal [4]. 


\section{WHAT ABOUT CIRCANNUAL RHYTHMS?}

As we mentioned before, circannual rhythms are just like circadian rhythms in that they rhythmically control our bodily processes, but instead of keeping time on a daily scale, circannual clocks run on a yearly scale. We see evidence of circannual clocks working in humans. When seasons change, we see a change in our mood and how our bodies digest the foods we eat [1]. These changes are thought to be due to melatonin, the same protein that helps us sleep at night. Our bodies produce melatonin when it is dark outside, so we produce more melatonin during the winter when days are shorter [1]. When built up to high concentrations in the blood, melatonin sends our bodies at least two different messages: (i) it is time for bed, and (ii) stop breaking down sugar [1]. So the increase in melatonin means we feel more tired in the winter and our appetites increase because we cannot break down sugar into energy as easily.

We see many more striking examples of circannual clocks in nature. For example, when tulips sense the coming spring and start to grow up through the ground, or when bears sense the coming winter and go into hibernation. Without circannual clocks, a tulip might bloom in the winter or a bear might not hibernate. As a result, the tulip would freeze and the bear would starve. How do the circannual clocks work? The organisms use cues, such as temperature and daylight, to determine the season. For instance, tulips (as well as other seasonal flowering plants) use exposure to cold and length of daylight to estimate the best time for flowering [5]. After a bulb has been exposed to the cold of winter and it senses the increasing temperature or daylight length associated with spring, it knows that it is the best time for flowering. Brown bears use temperature as a cue for hibernation-when the temperature drops below $0^{\circ} \mathrm{C}\left(32^{\circ} \mathrm{F}\right)$ a bear enters its den. When the temperature rises above $0^{\circ} \mathrm{C}$ the bear wakes up and leaves its den [6]. But what if these external cues start to shift over time, which may happen under climate change?

The rising temperatures associated with rapid climate change may confuse organisms' circannual rhythms, making them unable to properly time processes, such as hibernation or flowering. Bears may wake up too early or never hibernate! Migration in birds is another process that may be affected by rapid climate change. Many bird species use a combination of changing daylight length, temperature, and rainfall to determine when they should start their migration [7]. Migrating birds leave a breeding ground for warmer climates-this allows them to avoid the harsh winter weather and the poor food supplies that accompany it. They then return to breeding grounds in the following spring, when the weather improves and food is available again. Unfortunately, warmer temperatures may mean that a mismatch occurs between food abundance or weather conditions and the birds' movement. For example, if spring begins earlier and birds cannot 
adjust their migration, they will arrive at the wrong time and less food will be available [7].

\section{CONCLUSION}

Our internal clocks are vitally important for making sure our bodies are functioning normally. These clocks are present in all animals to help them stay alive. Internal clocks help our bodies to manage behaviors and bodily processes most efficiently. So, the next time you feel sleepy, hungry, or thirsty; remember that these feelings are not due to chance, but due to your circadian and circannual rhythms.

\section{REFERENCES}

1. Reppert, S. M., and Weaver, D. R. 2001. Molecular analysis of mammalian circadian rhythms. Annu. Rev. Physiol. 63:647-76. doi: 10.1146/annurev.physiol.63.1.647

2. Rahman, S. A., Kollara, A., Brown, T. J., and Casper, R. F. 2008. Selectively filtering short wavelengths attenuates the disruptive effects of nocturnal light on endocrine and molecular circadian phase markers in rats. Endocrinology 149:6125-35. doi: 10.1210/en.2007-1742

3. Ackerman, K., Revell, V. L., Lao, O., Rombouts, E. J., Skene, D. J., and Kayser, M. 2012. Diurnal rhythms in blood cell populations and the effect of acute sleep deprivation in healthy young men. Sleep 35:933-40. doi: 10.5665/sleep.1954

4. Faraut, B., Boudjeltia, K. Z., Vanhamme, L., and Kerkhofs, M. 2012. Immune, inflammatory and cardiovascular consequences of sleep restriction and recovery. Sleep Med. Rev. 16:137-49. doi: 10.1016/j.smrv.2011.05.001

5. Jung, C., and Müller, A. E. 2009. Flowering time control and applications in plant breeding. Trends Plant Sci. 14:563-73. doi: 10.1016/j.tplants.2009.07.005

6. Evans, A. L., Singh, N. J., Friebe, A., Arnemo, J. M., Laske, T. G., Fröbert, O., et al. 2016. Drivers of hibernation in the brown bear. Front. Zool. 13:7. doi: 10.1186/s12983-016-0140-6

7. Carey, C. 2009. The impacts of climate change on the annual cycles of birds. Philos. Trans. R. Soc. B 364:3321-30. doi: 10.1098/rstb.2009.0182

SUBMITTED: 24 January 2019; ACCEPTED: 03 May 2019; PUBLISHED ONLINE: 21 May 2019.

EDITED BY: Tansy C. Hammarton, University of Glasgow, United Kingdom

CITATION: Birchard KL and Leigh DM (2019) The Importance of Keeping Time With Our Internal Clocks. Front. Young Minds 7:72. doi: 10.3389/frym.2019.00072

CONFLICT OF INTEREST STATEMENT: The authors declare that the research was conducted in the absence of any commercial or financial relationships that could be construed as a potential conflict of interest.

COPYRIGHT () 2019 Birchard and Leigh. This is an open-access article distributed under the terms of the Creative Commons Attribution License (CC BY). The use, 


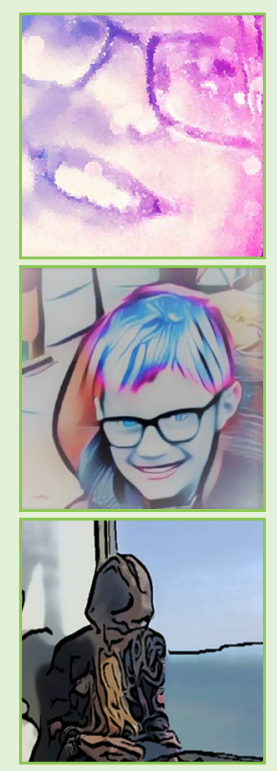

distribution or reproduction in other forums is permitted, provided the original author(s) and the copyright owner(s) are credited and that the original publication in this journal is cited, in accordance with accepted academic practice. No use, distribution or reproduction is permitted which does not comply with these terms.

\section{YOUNG REVIEWERS}

\section{CAITLIN, AGE: 12}

Caitlin is a 12 years old girl who likes cats, mermaids, and videogames and dislikes P.E. She enjoys spending time with her friends.

\section{EDWARD, AGE: 11}

Edward is an 11 years old boy who likes art and is fascinated by science. He likes to pass time by watching YouTube and playing on his Nintendo Switch. In the future he would like to become a computer engineer or technician.

\section{LOLA, AGE: 12}

A fun-loving bookworm who does not mind about fitting in. Lola is a budding author and actor who enjoys baking and dislikes P.E.

\section{AUTHORS}

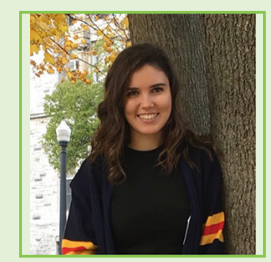

\section{KATIE L. BIRCHARD}

Katie Birchard is a master's degree candidate at Queen's University in Canada, where she also received her Bachelor of Science in biology. During her B.Sc., she studied how circadian genes vary with latitude in seabird colonies. She continues to study population genetics of seabirds.

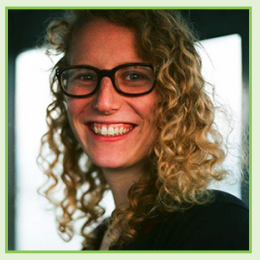

\section{DEBORAH M. LEIGH}

Deborah Leigh is a post-doctoral fellow and researches the genetics of endangered species. She studied in the UK and Switzerland, receiving her Ph.D. at the University of Zurich. She currently works in Switzerland and is trying to understand tree diseases. *deborahmleigh.research@gmail.com 